\title{
Authentic Assessment of Compulsory Subjects in Primary Schools: A Case Study in the Western Area of China
}

\author{
Jingyi Cheng* \\ Monash University, Melbourne, Victoria, Australia \\ *Corresponding author: Jingyi Cheng, jche0275@student.monash.edu
}

\begin{abstract}
This article discusses a case study that explores the relationship between 21 st century learning and curriculum alignment. It investigates three compulsory subjects: Chinese, mathematics, and English. By inquiring the survey on individual perspectives on curriculum content and authentic assessment in different schools within the scope of western Chinese primary schools, this article concluded that 21 st century learning skills are well developed in primary schools. Although authentic assessment from parents' perspective is diminutive, it is progressive for some students. Numerous factors can influence the actual practice of authentic assessment as teachers and pedagogies significantly contribute to students' learning outcomes. The authentic assessment in China still has a long way to go in order to boost these learning skills to a higher level.
\end{abstract}

Keywords: Primary education; 21st century learning skills; Curriculum alignment; Authentic assessment; Compulsory subjects

Publication date: September 2021; Online publication: September 30, 2021

\section{Introduction}

There are three compulsory subjects in the Chinese primary school system within the framework of education in China, which include Chinese, mathematics, and English. These core subjects accompany every school student throughout his or her academic life from primary to higher education. These critical prerequisite curricula are accompanied by intensive class arrangements and a substantial number of assessment tasks ${ }^{[1]}$. Recent policies and principles have highlighted the importance of 21 st century learning skills ${ }^{[2]}$. Consequently, there has been a shift in trend. An increasing number of compulsory subjects have started to adapt authentic assessment, which is known as a way to assess 21 st century learning skills ${ }^{[2,3]}$.

Authentic assessment contains historical and cultural factors. It is an integrated and sophisticated composition in the context of modern China facing transformations in the 21st century world. From a cultural perspective, compulsory education undertakes the critical task of cultivating people in order to construct a new age. Following its first introduction in China, authentic assessment is frequently associated with the term, quality education ${ }^{[4]}$. From a historical perspective, exam-oriented education, which is the opposite pole of quality education, was deeply embedded in Chinese education for over 1000 years. The aim of the education was to train professional workers with expertise suitable for the 20th century (Industrial Age) ${ }^{[3]}$. It aligned with rote memorization and recitation as the standard pedagogy and prescribed texts as its learning materials. In traditional learning approaches, teachers were the centre of the learning process. Several researchers have noticed the contradiction of having high scores in the examination but in practice, Chinese students have low capabilities ${ }^{[5]}$. This situation demands attention for 
the education system to switch from the past situation of compulsory education, which was aimed to ensure opportunities for education, to the recent implementation of quality education. At the same time, the changes in compulsory education emphasize on the cultivation of students' independent thinking as well as their practical and innovative skills ${ }^{[11]}$.

Therefore, implementing quality education and 21st learning skills are essential and are of priority. Collectively, they form the core of Chinese education framework.

\section{Key features, theory, and practices of authentic assessment}

Authentic assessment is 'progressive' in curriculum alignment and pedagogy (e.g., Dewey, Vygotsky, WIL). It comprises of activities or tasks for students to utilize and apply their knowledge and skills in 'reallife' or simulated scenarios ${ }^{[6]}$.

\subsection{Key features of authentic assessment}

The critical feature of authentic assessment aligns with progressive approaches in curriculum and pedagogy. Authentic assessment is student-centered, and it emphasizes diverse activities based on authentic, realworld experiences ${ }^{[4]}$. Its nature is that it shares authenticity and reality. Moreover, it is practically integrated and collaborative. Authentic assessment occurs in surroundings or cases that are simulated to real life or reality. In such surroundings and cases, students are required to apply their knowledge and skills to demonstrate their knowledge, reflect, collaborate, negotiate, and solve problems. The outcomes of authentic assessment are authentic, and they are in various forms. As an example, the learning outcomes are not merely the completion of the pages from workbooks or textbooks neither are they mechanically memorized transcriptions, or recitations of paragraphs, vocabularies, and notions. Instead, they are usually shown through mock cases, role-play performances, daily necessities, food, works of art, and writings based on reality.

The authentic assessment of curriculum alignment trains students to develop learning skills that match the 21 st century knowledge age ${ }^{[7]}$. In the authentic assessment of role-playing, students would select and act out their role with emotions. In order to do that, they need to analyze the character they would be playing critically and creatively. Besides, collaboration and communication within groups are also necessary. Hence, authentic assessment would be able to brew general skills, such as critical thinking, creative thinking, communication, collaboration and teamwork, social or emotional skills, as well as information and communication technology (ICT) skills, in line with 21 st century skills.

\subsection{Theory of authentic assessment}

Generally, there are three elements of authentic assessment in educational practice and five dimensions to evaluate and calculate the degree of authenticity in assessment ${ }^{[8,9]}$. The three elements in educational practice are as follows:

(1) authentic assessment should follow as authentic instructions to positively influence students' learning;

(2) students are required to demonstrate relevant competencies through accomplishments;

(3) the subjective perception of authenticity from students is vital in order to influence learning and can be constructed into a framework (Figure 1). 


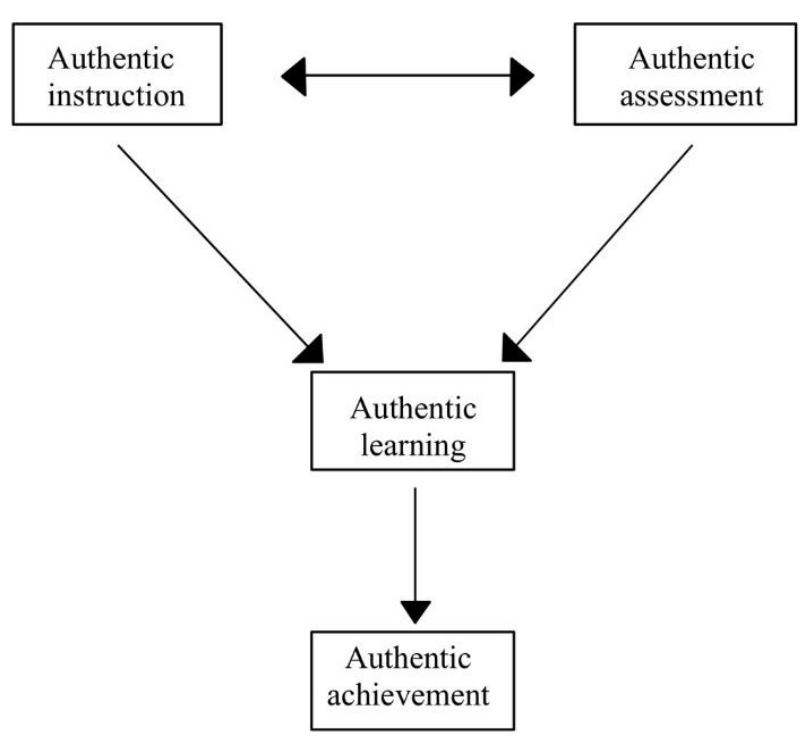

Figure 1. Subjective perception of authenticity framework

"The degree of authenticity is not solely a characteristic of the assessment chosen; it needs to be defined in relation to the criterion situation derived from professional practice ${ }^{[9]}$." Hence, it is possible to decide on the criterion situation by either increasing or decreasing the dimensions. Definitions and key features would be utilized to verify the authentic assessment and the five dimensions would decide on its level.

\subsection{Practice of authentic assessment}

From the context of the nine-year compulsory education in China, the practice of authentic assessment fits the features of 21 st century learning skills. However, it is just at the elementary or novice level. Undeniably, the educational policy considers the importance of quality education and prioritizes authentic assessment. One of the milestones of the Chinese education system is the high-stakes examination to gain entrance into colleges or universities. Although the requirement of quality education has been outlined in the main content of the educational policy, many middle schools disregard it. Under such circumstances, authentic assessment is a form of homework with practical characteristics. It is an informal assessment as it is ungraded by teachers.

In primary schools, authentic assessments are both formative and summative ${ }^{[10]}$. Hence, students are faced with less pressure in regard to their academic performances during high-stakes examinations. It is an ideal educational setting. Authentic assessment occurs in the teaching and learning process. Generally, practical activities are introduced at the end of each unit or summary of each class.

\section{Relationship between authentic assessment and the curriculum of compulsory subjects}

As for curriculum alignment, the discussion of authentic assessment in primary schools also includes the curriculum. Primary school students are divided from grade 1 to grade 6 according to their ages and the difficulty. There are several editions of textbooks for different levels, which have been edited with the same standard and published by the Ministry of Education ${ }^{[11]}$. In other words, the decision for the intended curriculum in primary schools at different areas belongs to the Ministry of Education of the People's Republic of China ${ }^{[2]}$. 


\subsection{Authentic assessment in the Chinese subject}

The Chinese subject includes two parts: Chinese language and Chinese literature arts ${ }^{[1,12]}$. The elementary level (grade 1-3) Chinese textbook includes Chinese language learning. Chinese language learning includes alphabetic literacy, writings of Chinese characters, vocabulary, phrases, and short sentences. Following the learning period, there are interesting activities (group discussions and role-playing) at the end of each class and a summary at the end of each unit (speeches or debate competitions, topics for oral presentations, theme writing tasks, etc.). For instance, grade 1 includes singing songs and finding the meaning of one's name; grade 2 includes role-playing games and handcrafts; grade 3 includes polite dialogues in diverse situations: asking for directions, expressing feelings, convince someone to break bad habits, making friends with one's classmates, etc.

Meanwhile, from grade 4 to grade 6, the Chinese textbook mostly focuses on literature appreciation. The articles contain moral, ideological, psychological, mythical, and historical stories, as well as some traditional Chinese culture. Besides, students would systematically learn writing skills. They are required to either read books, watch movies, perform self-reflection (report), or compile a record of the things which had happened in their daily lives (diary). Simultaneously, the literacy of expression becomes more complex. Sometimes students need to observe and practice. The highest level in these grades is to design a topic by outlining the point and summarizing the ideas or work in a well-organized essay.

Several examples of learning activities which are related to the 21 st century learning skills in authentic assessment in line with the curriculum objectives in the Chinese subject are shown in Table $\mathbf{1 .}$

Table 1. Authentic assessment in the Chinese subject

\begin{tabular}{|c|c|c|c|}
\hline Grade & Content & Form of authentic assessment & Skills designed to improve \\
\hline 1 & $\begin{array}{l}\text { Singing songs with } \\
\text { Chinese alphabets }\end{array}$ & $\begin{array}{l}\text { - Recording while singing songs } \\
\text { - Performances }\end{array}$ & $\begin{array}{l}\text { - Knowledge memorization } \\
\text { - Knowledge application into new formations } \\
\text { - ICT skills if recording is involved }\end{array}$ \\
\hline 2 & Role-playing & $\begin{array}{l}\text { - Recording of the role-play } \\
\text { - Performances }\end{array}$ & $\begin{array}{l}\text { - Critical and creative thinking skills } \\
\text { - Social or emotional skills in performances } \\
\text { - ICT skills if recording is involved }\end{array}$ \\
\hline 3 & $\begin{array}{c}\text { Oral } \\
\text { communication } \\
\text { (Helping one } \\
\text { student to form a } \\
\text { good habit in } \\
\text { reading) }\end{array}$ & $\begin{array}{l}\text { - Recordings of various communication } \\
\text { - Essays about communication } \\
\text { - Performances based on situations }\end{array}$ & $\begin{array}{l}\text { - Critical and creative thinking skills in } \\
\text { analyzing situations } \\
\text { - Communication skills } \\
\text { - Social or emotional skills in cross-culture, } \\
\text { open-minded, respectful conversations } \\
\text { - Problem-solving skills in specific situations } \\
\text { - ICT skills if recording is involved }\end{array}$ \\
\hline 4 & Traveling report & $\begin{array}{l}\text { - Lectures or speeches on traveling } \\
\text { - Writing for traveling } \\
\text { - Peer-review and reflection } \\
\text { - Photo album with notations or PowerPoint } \\
\text { slides }\end{array}$ & $\begin{array}{l}\text { - Communication skills or presentation skills } \\
\text { by lectures } \\
\text { - Critical and creative thinking in reflecting } \\
\text { opinions about traveling } \\
\text { - Information synthesizing, constructing, } \\
\text { evaluating, and comparing with different } \\
\text { opinions in regard to travel sites } \\
\text { - ICT skills if PowerPoint slides are used or } \\
\text { photos are displayed on media player }\end{array}$ \\
\hline
\end{tabular}

(Continued on the next page) 
(Continued from the previous page)

\begin{tabular}{|c|c|c|c|}
\hline Grade & Content & Form of authentic assessment & Skills designed to improve \\
\hline 5 & $\begin{array}{l}\text { Thematic class } \\
\text { meeting about } \\
\text { mental health }\end{array}$ & $\begin{array}{l}\text { - Simulated class meetings } \\
\text { - Detailed plan of thematic class meetings } \\
\text { - Hand-copied newspaper of a theme } \\
\text { - Performances }\end{array}$ & $\begin{array}{l}\text { - Critical and creative thinking skills in } \\
\text { organizing the ideas of a theme } \\
\text { - ICT skills in data collection and information } \\
\text { analyzing } \\
\text { - Communication skills in public presentations } \\
\text { or integrating texts and images in newspapers } \\
\text { - Leadership skills in terms of mobilizing other } \\
\text { students } \\
\text { - Collaboration and teamwork with different } \\
\text { cultural backgrounds }\end{array}$ \\
\hline 6 & $\begin{array}{c}\text { Essay about the } \\
\text { future }\end{array}$ & $\begin{array}{l}\text { - Creative essay about the future based on } \\
\text { the reality and recent development of } \\
\text { technology }\end{array}$ & $\begin{array}{l}\text { - Critical and creative thinking skills in } \\
\text { drawing clues from reality (reasoning and } \\
\text { constructing arguments) }\end{array}$ \\
\hline
\end{tabular}

The chart clearly shows that the learning content in each grade of the Chinese subject stresses on authentic assessment. There is a vast number of learning contents related to authentic assessment in each class (think, discuss, and share one's opinion) and units after several classes (group activities, oral communication, observation, essay, etc.) The significant number of authentic tasks ensures that students have sufficient opportunities to continually foster 21 st century learning skills in communication, collaboration, teamwork, social, emotion, and creative thinking. The validity of authentic assessment in critical skills is primarily trained in writing tasks. All writing tasks do not mirror reality; for higher-level primary schools (grade 4 to grade 6), authentic curriculum is rare but literacy and writing skills are prerequisites. Since there is no fixed textbook, ICT skills are dynamic and predictable in Chinese learning. Besides, the substantial requirement and dependence on equipment in digital learning rely on educational resources. In the western area of China, the official investment of educational resources in schools is below the average level ${ }^{[13]}$. Meanwhile, the high penetration and ownership rate for smartphones in families is another factor that continually requires and develops ICT skills.

\subsection{Authentic assessment in mathematics}

Mathematics shares the same status as Chinese in compulsory education. In elementary level education, students aim to learn numeracy. Broadly stating, numeracy includes a sense of numbers, awareness of operations, computation, measurement, geometry, probability, statistics, management, and responsiveness to practical mathematical demands in life. The curriculum design follows the aim of compulsory education numeracy ${ }^{[14]}$. The examples of practical activities in the mathematics textbook are shown in Table 2. 
Table 2. Authentic assessment in mathematics

\begin{tabular}{|c|c|c|c|}
\hline Grade & Content & Form of authentic assessment & Skills designed to improve \\
\hline 1 & $\begin{array}{l}\text { Geometric figure and } \\
\text { solid figure }\end{array}$ & $\begin{array}{l}\text { - Finding or counting the figures by observation } \\
\text { - Tangram }\end{array}$ & $\begin{array}{l}\text { - Observation skills } \\
\text { - Reflection }\end{array}$ \\
\hline 2 & $\begin{array}{l}\text { Meters and } \\
\text { centimeters }\end{array}$ & $\begin{array}{l}\text { - Guessing the length of an object } \\
\text { - Measuring and verifying the conjecture }\end{array}$ & \multirow{5}{*}{$\begin{array}{l}\text { - Critical thinking skills by analyzing } \\
\text { and synthesizing information } \\
\text { - Reasoning and constructing arguments } \\
\text { - Evaluating, critiquing, and } \\
\text { constructing criteria } \\
\text { - Comparing and making connections }\end{array}$} \\
\hline 3 & $\begin{array}{l}\text { Directions and } \\
\text { locations }\end{array}$ & $\begin{array}{l}\text { - Observing the rising and setting (or positions) } \\
\text { of the sun and moon } \\
\text { - Figuring the relative positions of students' } \\
\text { homes }\end{array}$ & \\
\hline 4 & $\begin{array}{l}\text { Statistics of students' } \\
\text { interest }\end{array}$ & $\begin{array}{l}\text { - Making a census data within class } \\
\text { - Categorizing survey examples } \\
\text { - Making simple bar charts } \\
\text { - Figuring out the highest and lowest samples } \\
\text { - Making summaries and calculating the average }\end{array}$ & \\
\hline 5 & Volume of solid & $\begin{array}{l}\text { - Measuring length, width, and height } \\
\text { - Calculating volume }\end{array}$ & \\
\hline 6 & Percentage & $\begin{array}{l}\text { - Simulating a banking situation of currency } \\
\text { investment } \\
\text { - Buying deposits or financial products and } \\
\text { calculating money rates }\end{array}$ & \\
\hline
\end{tabular}

In general, mathematics is everywhere in life. It is often regarded as the closest relationship between math and practice ${ }^{[15]}$. Compared with Chinese oral communication or writing tasks, there is a lesser number of practical tasks in mathematics. This is because in each semester, there are only one or two activities after several units. Instead, the standard pages in textbooks are computations: horizontal type, vertical type, decimal calculation, addition, subtraction, multiplication, and division. Besides, certain application-type mathematics problems (real-life mathematics problems) often exist in examination papers and workbooks. For instance, students would be required to provide solutions and plans for tickets, use money to purchase items, calculate the speed and distance for a moving subject, calculate the square and volume in gardens, planting trees, etc. The mathematics world provides simulated situations. Students need to solve problems by analyzing the information, matching the information with a mathematical model, logically thinking of the methods that can be used, finding out a suitable formula, as well as substituting accurate numbers into the formula and calculating. Problem-solving skills can be significantly improved through Linear Equation with One Unknown in grade 6.

The critical discussion is: Do mathematics problems belong to authentic assessment, and do they improve 21 st century learning skills? From the definition and theoretical framework, mathematics problems belong to authentic assessment as students are assessed based on their abilities to use and apply knowledge as well as skills in simulated situations to solve problems ${ }^{[10]}$. The product is a solution or a strategy with mathematical ideology. However, the quality of the simulated questions is not effective in fostering $21 \mathrm{st}$ century learning skills. The validity of the problems is low in communication, collaboration skills, and social or emotional thinking ${ }^{[9]}$. From a teachers' perspective, independent logical thinking is more important than exchanging ideas for a solution because sharing of ideas is misconstrued as laziness or plagiarism. Meanwhile, critical thinking, creative thinking, and ICT skills are highlighted. In a defined situation, students need to collect every piece of information. Creative thinking skills would enable them 
to look for alternative possibilities and perspectives to generate solutions upon analyzing and synthesizing information. Occasionally, students are required to learn how to use a calculator for computations.

\subsection{Authentic assessment in mathematics}

English learning in primary schools is an exception. Unlike the Chinese subject, which accompanies students from grade 1 to grade 6, the English subject is offered from grade 3 to grade $6^{[16]}$. The curriculum alignment in the English subject is different from that in the Chinese subject. This is due to the primary school setting where students do not need to appreciate English literacy and passages but only required to learn about phonetic symbols, alphabets, vocabularies, phrases, and short sentences. The peak of English learning in primary schools is conversation and translation. The overall learning content is divided into situational units. For instance, First to School, Daily Routine, Likes and Dislikes, Family and Society, Travel and Lifestyle, etc. The association between authentic assessment and learning content is shown in Table 3.

The unit design of English learning is based on real situations and focuses on communication as well as oral practice. In the authentic assessment of guessing and drawing as well as thinking and matching, students will have the opportunity to practice creative thinking and social or emotional skills. Playing games and other conversational activities would improve students' communication skills.

Overall, the curriculum provides a simulated contextual situation in educational practice within each subject to a certain extent. Furthermore, it aims at 21 st century general skills, which combines progressive assessment and feedback on the teaching and learning content.

Table 3. Authentic assessment in the English subject

\begin{tabular}{cccc}
\hline \multicolumn{3}{c}{ Unit 4: What's for Breakfast } \\
\hline Content & \multicolumn{3}{c}{ Activities } \\
\hline Part A & Drawing out your likes or dislikes & Thinking and matching & Singing and chanting \\
Part B & Playing games & Conversation & \\
Part C & Workbook for grammar & & \\
\hline
\end{tabular}

\section{Relationship between authentic assessment and pedagogy}

A constructive alignment between instruction, learning, and assessment (ILA) is necessary to match the progressive approaches ${ }^{[17]}$. Under the authentic and simulated curriculum content, pedagogies are the main factors that influence the actual educational practice. Many literatures have emphasized on teachers' behaviors in the relationship between authentic assessment and pedagogy. For example, teachers providing instructions to support the classroom, collecting evidence from multiple activities, promoting learning and teaching among participants, as well as reflecting local values, standards, and controls ${ }^{[18]}$. Hammond suggested that teachers need to be skillful in evaluating teaching situations and developing effective teaching responses under different circumstances ${ }^{[19]}$. Puckett and Black's “four P's," which include process, performance, products, and portfolios, are crucial dimensions of authentic assessment for school-aged children ${ }^{[10]}$.

Therefore, teachers should be responsive, reactive, and professional in organizing teaching and learning activities ${ }^{[20]}$. Specifically, classroom observation and integrated information within and outside the context are necessary. Tools such as cases, portfolios that assemble artifacts of practice, exhibitions of performance, and problem-based inquiries should be used to assess students' learning ${ }^{[22]}$. 
However, there is no official evaluations or examinations for public primary school teachers. Their theoretical understanding and contextualized practice are uncertain, which can only be explored by external factors.

In the survey of the practice of authentic assessment in western Chinese primary schools as shown in Table 4, more than $56 \%$ of students and parents felt that authentic assessment is only for parents but not for students. In addition, $30.77 \%$ of them also felt that the rubric from teachers is not clear enough for students to finish their tasks, which is the flaw of teachers.

Increasing the authenticity of an assessment is expected to positively influence students' learning and motivation ${ }^{[20,21]}$. However, in China's western area, the high complaint rate of teachers in authentic assessment shows that it is not ideal. Besides, more than about $30 \%$ of the students complained that they do not have enough time for extra authentic assessment as they usually spend more than 0.5-2 hours for studying.

Table 4. Reasons against authentic assessment

\begin{tabular}{cc}
\hline Reasons & Percentage \\
\hline No clear instructions & $30.77 \%$ \\
Seemingly for parents but not for students & $51.28 \%$ \\
No access to references (e.g., internet, library sources) & $56.41 \%$ \\
Increases the number of assessment tasks and reduces spare time & $50 \%$ \\
Gees against academic achievements & $42.31 \%$ \\
Remains in format and neglects the real practice & $28.21 \%$ \\
foo many discouraging factors (e.g., different levels in discussion groups, digital divide, & $16.67 \%$ \\
family issues, etc.) & $28.21 \%$ \\
\hline
\end{tabular}

\section{Do authentic assessments improve students' achievement?}

In regard to the features of authentic assessment, real and practical activities assist students to learn and experience from the real world. The best tests always teach students to be enabling and forward-looking, not just reflective beings of prior teaching ${ }^{[23]}$.

\subsection{Students' perceptions of authentic assessment}

Based on Table 5, most pupils showed enthusiasm about authentic assessment in language subjects (Chinese and English), where more than $70 \%$ of students preferred authentic assessment, which was higher compared to that in mathematics. When being asked the reason for it, it has been found that students do not like calculating procession and the word problems in mathematics are not close to reality. 
Table 5. Reflections about authentic assessment in Chinese, mathematics, and English

\begin{tabular}{cccccc}
\hline $\begin{array}{c}\text { 5-point Likert } \\
\text { scale }\end{array}$ & $\begin{array}{c}\text { Do not like to an } \\
\text { extreme extent }\end{array}$ & $\begin{array}{c}\text { Do not like to } \\
\text { some extent }\end{array}$ & Normal & $\begin{array}{c}\text { Like to some } \\
\text { extent }\end{array}$ & $\begin{array}{c}\text { Like to an } \\
\text { extreme extent }\end{array}$ \\
\hline Chinese & $0 \%$ & $7.69 \%$ & $42.31 \%$ & $42.31 \%$ & $7.69 \%$ \\
Mathematics & $5.13 \%$ & $15.38 \%$ & $43.59 \%$ & $25.64 \%$ & $10.26 \%$ \\
English & $2.56 \%$ & $14.1 \%$ & $34.62 \%$ & $43.59 \%$ & $5.13 \%$ \\
\hline
\end{tabular}

Student A mentioned that role-playing and group discussions were her favorite activities as she could meet her friends and complete activities together. That was the most entertaining part in role-playing. Meanwhile, student B mentioned, "I like doing handcrafts and drawing on my own. As long as I am required to make products rather than filling in pages from workbooks, compulsory classes are interesting."

According to the data in Table 6, more than half of the students felt that they were able to train their skills by authentic assessment $(56.41 \%$ in critical thinking, $52.56 \%$ in creative thinking, $51.28 \%$ in communication, and $26.92 \%$ in ICT skills).

Table 6. Reasons for liking authentic assessment

\begin{tabular}{|c|c|}
\hline Reasons & Percentage \\
\hline Content and formation are new and novel & $29.49 \%$ \\
\hline Develops critical thinking skills & $56.41 \%$ \\
\hline Develops creative skills & $52.56 \%$ \\
\hline Improves practical skills & $48.72 \%$ \\
\hline Improves communication skills & $51.28 \%$ \\
\hline Enhances the sense of realistic experience and preliminary understanding of the society and life & $38.46 \%$ \\
\hline Enables one to learn the latest scientific and technological knowledge by using the network & $26.92 \%$ \\
\hline Exercises the comprehensive ability & $14.1 \%$ \\
\hline Engaging and more interesting compared to traditional workbooks & $11.54 \%$ \\
\hline Easier and less time-consuming compared to traditional workbooks & $7.69 \%$ \\
\hline
\end{tabular}

\subsection{Parents' perceptions of authentic assessment}

Unlike students, most parents hold a negative attitude toward authentic assessment.

Parent A mentioned, "Practical homework is good, but they are only good for parents, not the students. Students are unable to complete such difficult activities by themselves, thus requiring a lot of help from their parents."

A former parent that was interviewed for this article felt that practical homework was too timeconsuming: "Homework such as designing a product or a performance is useless as students only draw 
pictures, copy from the internet, or carry out rehearsals. I do not think that these tasks would directly help students achieve higher marks. It is also time-consuming. I prefer teachers to provide more workbooks and exam papers. I do not want my children to be left behind even in primary school; what if they are not able to catch up in the next level?"

On the other hand, a parent agreed on the importance of authentic assessment in primary schools: "Practical homework is useful for the future but not for now. It triggers my son's interest in many things. The earlier he engages into the society, the better he understands about real life."

\section{Conclusion}

In conclusion, authentic assessment within the context of China in primary school settings involves the elementary level. The policy makers are fully aware of the importance of authentic assessment and the 21st century learning skills behind it. As a result, the nine-year compulsory education law shows a trend in the compulsory subjects, concluding the progressive and practical learning content (learning activities textbook) or hidden curriculum (word problems) as intended. However, the actual practice of authentic assessment is defined by the pedagogies, wherein the western area of China is insufficient in educational resources, specifically in the quality of teachers. Primary schools have not been apparent in testifying the real and significant effect of authentic assessment; thus, parents hold a negative or neutral attitude toward it. Only a few families seriously consider authentic assessment and train their learning skills within it. There is still a long way to go for the authentic assessment in western Chinese primary schools.

There are several implications from policy makers, research, and practice. From the leadership perspective, although the government has paid attention to textbooks (curriculum), much more effort is required in the rest of the curriculum alignment (pedagogy and assessments). For instance, the Ministry of Education should consider the educational resources in different areas in terms of the quality of teachers. The policy should improve the standards for teachers' entrance qualification and ensure that teachers would stick to the policy by placing authentic teaching and learning as a priority in quality education. It is possible for governments to also provide systematic training before their teaching career in order to cultivate teachers to be professional organizers with practical expertise. In terms of assessment, educational leaders should transfer some of the concentration on high-stakes examinations to authentic assessment. In this article, the relationship between pedagogy and authentic assessment is mainly based on the survey of parents' and students' perspectives. Research should emphasize more on local academic development, such as interviewing the principals or teachers. Moreover, this is a case study of the western area in China, where this situation widely exists and needs to be discussed. The practice of authentic assessment involves both the parents and students. Both parties should be more active in regard to practical assessment, and not limited to the knowledge within school settings.

In general, the balance and unity of authentic curriculum alignment from policy, school settings, teachers, and families would bring about the actual practice of authentic learning, fostering the 21 st century development.

\section{Disclosure statement}

The author declares that there is no conflict of interest.

\section{References}

[1] Hayhoe R, 2019, Contemporary Chinese Education, Routledge, 47-64.

[2] Yin D, 2020, A Policy Review on Chinese Compulsory Education Quality Assessment: What We Learned from Official Reports Released in 2018 and 2019. ECNU Review of Education, : 1-14. 
https://doi.org/10.1177/2096531120944522

[3] Trilling B, Fadel C, 2009, 21st Century Skills, Enhanced Edition: Learning for Life in Our Times, John Wiley \& Sons, 3-19.

[4] Heitink MC, Van der Kleij FM, Veldkamp BP, et al., 2016, A Systematic Review of Prerequisites for Implementing Assessment for Learning in Classroom Practice. Educational Research Review, 17: 5062. https://doi.org/10.1016/j.edurev.2015.12.002

[5] Huang F, 2004, Curriculum Reform in Contemporary China: Seven Goals and Six Strategies. Journal of Curriculum Studies, 36(1): 101-115. https://doi.org/10.1080/002202703200004742000174126

[6] Fook CY, Sidhu GK, 2010, Authentic Assessment and Pedagogical Strategies in Higher Education. Journal of Social Sciences, 6(2): 153-161.

[7] Voogt J, Roblin NP, 2012, A Comparative Analysis of International Frameworks for 21st Century Competences: Implications for National Curriculum Policies. Journal of Curriculum Studies, 44(3): 299-321. https://doi.org/10.1080/00220272.2012.668938

[8] Cronin JF, 1993, Four Misconceptions About Authentic Learning. Educational Leadership, 50(7): 78 80 .

[9] Gulikers JT, Bastiaens TJ, Kirschner PA, 2004, A Five-Dimensional Framework for Authentic Assessment. Educational Technology Research and Development, 52(3): 67.

[10] Frey BB, Schmitt VL, Allen JP, 2012, Defining Authentic Classroom Assessment. Defining Authentic Classroom Assessment, 17(2):1-18. https://doi.org/https://doi.org/10.7275/sxbs-0829

[11] Ministry of Education of the People's Republic of China, 2019, The Textbook Compiled by the Ministry Was Launched in September and Was "Praised" by More Than $90 \%$ of Students. http://www.moe.gov.cn/fbh/live/2019/51084/mtbd/201908/t20190828_396253.html

[12] Curdt C, Xiao L, 2021, Environmental Literacy: Raising Awareness Through Chinese Primary Education Textbooks. Language. Culture and Curriculum, 34(2): 147-162.

[13] Liu X, Lu K, 2008, Student Performance and Family Socioeconomic Status: Results from a Survey of Compulsory Education in Western China. Chinese Education \& Society, 41(5): 70-83. https://doi.org/10.2753/CED1061-1932410505

[14] Ministry of Education of the People's Republic of China, 2019, Textbooks of Compulsory Education (Mathematics), People's Education Press.

[15] Georgetown University Math C, 1997, Dances with Calculators. Math Horizons, 5(1): 23-27. http://www.jstor.org/stable/25678124

[16] Ministry of Education of the People's Republic of China, 2019, Textbooks of Compulsory Education (English), Shaanxi Travel Press.

[17] Riley KL, Stern BS, 1998, Using Authentic Assessment and Qualitative Methodology to Bridge Theory and Practice. The Educational Forum, 62: 178-185.

[18] Wiggins G, 1990, The Case for Authentic Assessment. Practical Assessment, Research \& Evaluation, 2(2): 1-3. https://doi.org/https://doi.org/10.7275/ffb1-mm19

[19] Hammond LD, 2012, Policy Frameworks for New Assessments, in Assessment and Teaching of 21st Century Skills, Springer, 301-309.

[20] Kippers WB, Wolterinck CH, Schildkamp K, et al., 2018, Teachers' Views on the Use of Assessment for Learning and Data-Based Decision Making in Classroom Practice. Teaching and Teacher Education, 75: 199-213. https://www.journals.elsevier.com/teaching-and-teacher-education 
[21] Linda DH, Jon S, 2000, Authentic Assessment of Teaching in Context. Teaching and Teacher Education, 16(5): 523-545. https://doi.org/https://doi.org/10.1016/S0742-051X(00)00015-9

[22] Wiggins G, 1991, Teaching to the (Authentic) Test, in Costa A, Developing Minds, A Resource Book for Teaching Thinking, Asociación Para La Supervisión Del Desarrollo Del Curriculum, ASCD, USA, $1,344-350$. 